\section{PENGEMBANGAN}

\section{KURIKULUM PESANTREN}

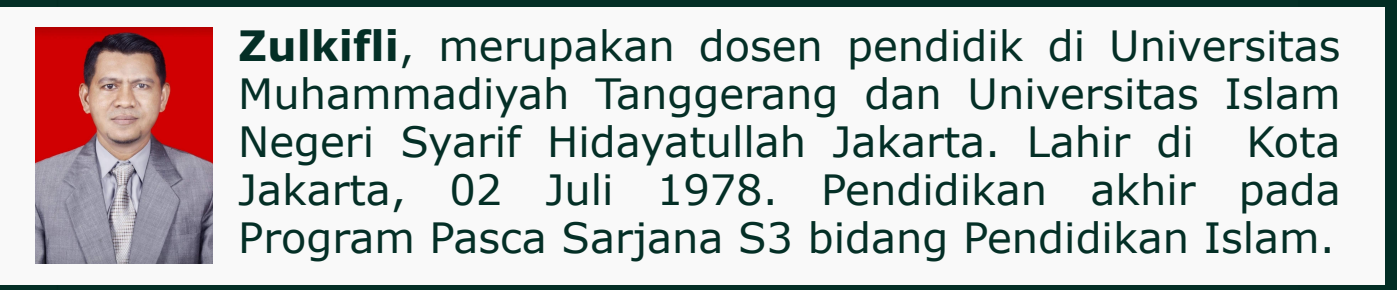

Kurikulum merupakan sebuah ruh dalam dunia pendidikan, dengan makna bahwa kurikulum merupakan salah satu komponen dari beberapa komponen lainnya, yang akan menentukan kemana arah maju atau mundurnya kualitas pendidikan dalam suatu lembaga secara khusus dan dalam sebuah negara agar lebih luas lagi. Pengembangan kurikulum mempunyai makna yang cukup luas, Menurut Sukmadinata, pengembangan kurikulum bisa berarti penyusunan kurikulum yang sama sekali baru (curriculum construction), bisa juga menyempurnakan kurikulum yang telah ada (curriculum improvement). Selanjutnya beliau juga menjelaskan, pada satu sisi pengembangan kurikulum berarti menyusun seluruh perangkat kurikulum mulai dari dasar-dasar kurikulum, struktur dan sebaran mata pelajaran, garis-garis besar program pengajaran, sampai dengan pedoman-pedoman pelaksanaan (macro curriculum).

Dari segi kurikulum, pesantren selama ini diberi kebebasan oleh Negara untuk menyusun dan melaksanakan kurikulum pendidikan secara bebas dan merdeka. Namun demikian, jika dilihat dari studistudi tentang pesantren diperoleh bentuk-bentuk kurikulum yang ada di kalangan pesantren. Menurut Lukens Bull, secara umum kurikulum pesantren dapat dibedakan menjadi empat bentuk, yaitu: (1) pendidikan agama, (2) pengalaman dan pendidikan moral, (3) sekolah dan pendidikan umum, serta (4) keterampilan dan kursus. Dalam buku ini membahas mengenai pengembangan kurikulum tentang kepribadian santri dalam menciptakan karakter mandiri, disiplin dan berdikari serta memiliki jiwa keikhlasan

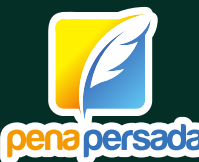

\section{ZULKIFLI}
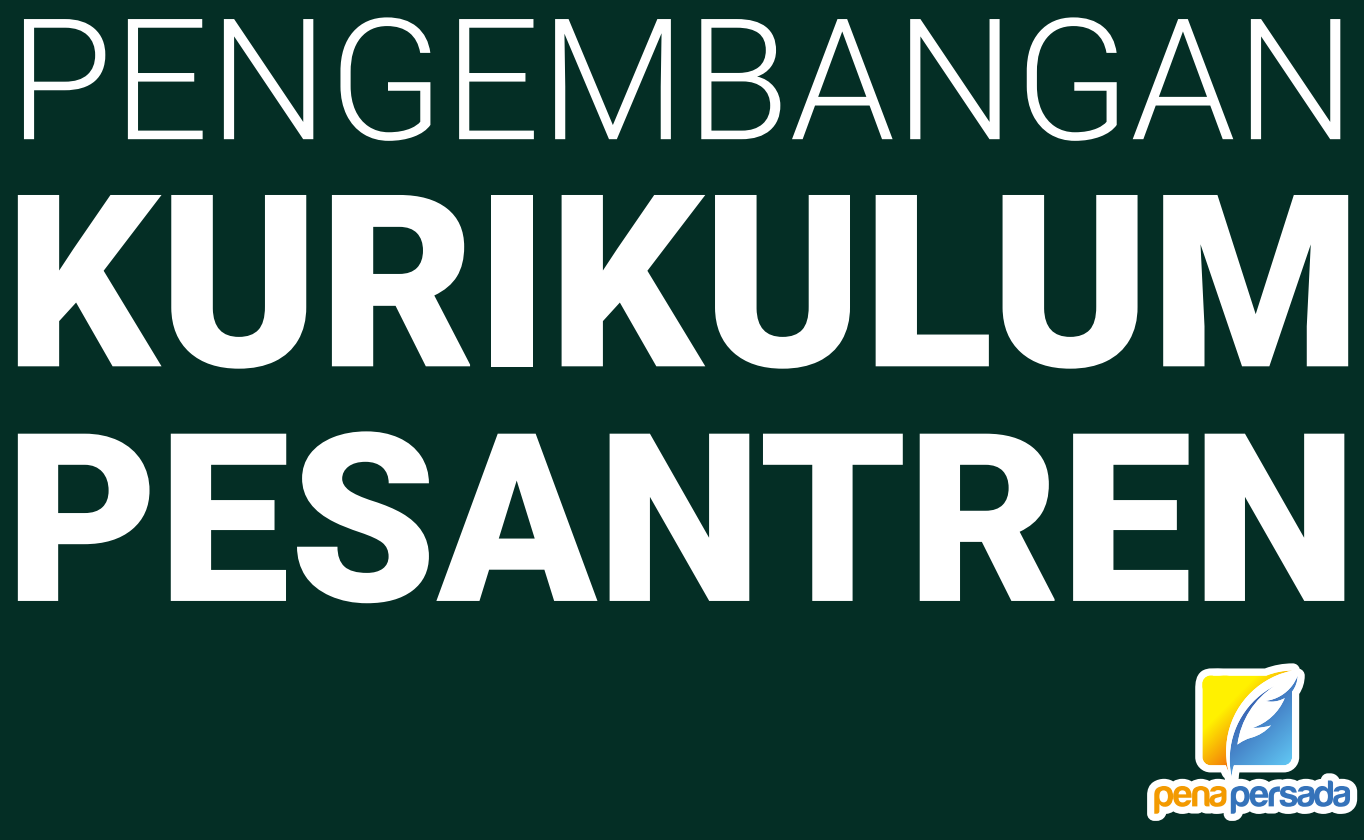


\title{
PENGEMBANGAN KURIKULUM PESANTREN
}

\author{
ZULKIFLI
}

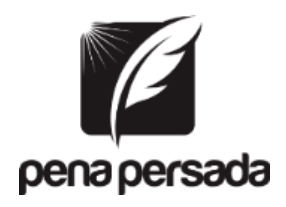

PENERBIT CV. PENA PERSADA 


\section{PENGEMBANGAN KURIKULUM PESANTREN}

Penulis:

Zulkifli

ISBN : 978-623-315-399-7

Editor:

Wiwit Kurniawan

Design Cover :

Retnani Nur Briliant

Layout :

Eka Safitry

\section{Penerbit CV. Pena Persada}

Redaksi :

Jl. Gerilya No. 292 Purwokerto Selatan, Kab. Banyumas

Jawa Tengah

Email : penerbit.penapersada@gmail.com

Website : penapersada.com Phone : (0281) 7771388

\section{Anggota IKAPI}

All right reserved

Cetakan pertama : 2021

Hak Cipta dilindungi oleh undang-undang. Dilarang memperbanyak karya tulis ini dalam bentuk apapun tanpa izin penerbit 


\section{KATA PENGANTAR}

Segala puji senantiasa kita panjatkan kehadirat Allah SWT, atas segala rahmat dan karunianya, akhirnya penulis dapat menyelesaikan penyusunan buku yang berjudul “ PENGEMBANGAN KURIKULUM PESANTREN". Saya menyadari bahwa tanpa bantuan dan bimbingan dari berbagai pihak sangatlah sulit bagi saya untuk menyelesaikan karya ini. Oleh karena itu, saya mengucapkan banyak terima kasih pada semua pihak yang telah membantu penyusunan buku ini. Sehingga buku ini bisa hadir di hadapan pembaca.

Pentingnya kedudukan pesantren dalam mencapai tujuan pendidikan nasional sudah diakui banyak kalangan. Pesantren telah diakui sebagai lembaga pendidikan yang telah diakui sebagai lembaga pendidikan yang telah ikut serta mencerdaskan kehidupan bangsa dan sekaligus mengangkat harkat bangsa. Terutama di zaman kolonial, pesantren merupakan lembaga pendidikan yang sangat berjasa bagi umat Islam. Para peneliti terdahulu mengatakan bahwa pesantren adalah hasil rekayasa umat Islam Indonesia yang mengembangkan dari sistem pendidikan agama Jawa (abad ke 8 sampai $9 \mathrm{M}$ ), merupakan perpaduan antara kepercayaan Animisme, Hinduisme dan Budhisme. Sistem pendidikan tersebut diambil alih dengan mengganti 
nilai ajarannya menjadi nilai ajaran Islam. Dalam buku ini membahas mengenai pengembangan kurikulum tentang kepribadian santri dalam menciptakan karakter mandiri, disiplin dan berdikari serta memiliki jiwa keikhlasan.

Penulis menyadari bahwa buku ini masih jauh dari kesempurnaan. Oleh karena itu kritik dan saran yang membangun sangat dibutuhkan guna penyempurnaan buku ini. Akhir kata saya berharap Allah SWT berkenan membalas segala kebaikan semua pihak yang telah membantu.

Penulis 


\section{DAFTAR ISI}

KATA PENGANTAR ........................................................... iii

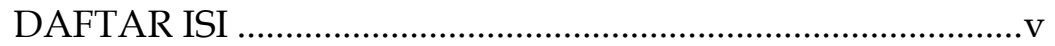

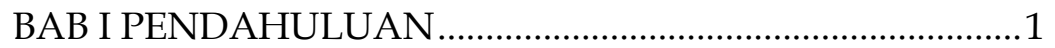

A. Pengertian Kurikulum.................................................

B. Pengembangan Kurikulum ....................................17

BAB II MODEL-MODEL PENGEMBANGAN

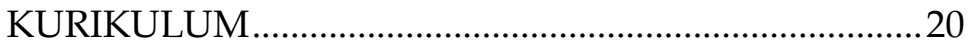

A. Model Administrative (line-staff) Model ................22

B. The Grass Roots Model. .............................................22

BAB III EVALUASI KURIKULUM .......................................2 24

A. Pengertian Kepribadian ...........................................26

B. Struktur Kepribadian ................................................29

C. Dinamika Kepribadian dalam Perspektif Islam .....34

D. Faktor-Faktor yang Membentuk Kepribadian........42

1. Aliran Empirisme .............................................. 42

2. Aliran Nativisme ................................................. 43

3. Aliran Konvergensi .............................................. 44

E. Penjelasan Tentang Kepribadian ................................47 
F. Unsur-unsur dari kepribadian

G. Pengertian Kepribadian Menurut Para Pakar atau Ahli

BAB IV KURIKULUM KEPRIBADIAN SANTRI 54

A. Sistem Kurikulum Pendidikan Pondok Pesantren .66

B. Pengembangan Kurikulum Pesantren .73 DAFTAR PUSTAKA 82 


\section{BAB I}

\section{PENDAHULUAN}

\section{A. Pengertian Kurikulum}

Istilah kurikulum memiliki berbagai tafsiran yang dirumuskan oleh pakar- pakar pengembangan kurikulum sejak dulu sampai sekarang, tafsiran itu berbeda beda satu dengan yang lainnya sesuai dengan titik berat inti dan pandangan dari yang bersangkutan. ${ }^{1}$ Secara etimologis curriculum berasal dari bahasa Yunani kuno, yaitu curir yang artinya pelari dan curere yang berarti tempat berpacu, jadi istilah kurikulum pada zaman romawi kuno mengandung pengertian sebagai suatu jarak yang harus ditempuh oleh pelari dari garis start sampai garis finish. ${ }^{2}$ Pada saat itu kurikulum diartikan sebagai jarak yang harus ditempuh oleh seorang pelari mulai dari start sampai finish ${ }^{3}$. Kurikulum muncul pertama kalinya di Skotlandia

Oemar Hamalik, Kurikulum dan Pembelajaran, Jakarta : Bumi Aksara, 2017, 16

Sholeh Hidayat. Pengembangan Kurikulum Baru. Bandung: Remaja Rosdakarya, 2013, 19

Subandijah, Pengembangan dan Inovasi Kurikulum, (Jakarta: Raja Grafindo Persada, 1993), 1. 
sekitar tahun 1829, secara resmi istilah ini baru dipakai hampir satu abad. ${ }^{4}$

Dalam bahasa Arab, istilah kurikulum dikenal dengan istilah manhaj, yaitu jalan yang terang atau jalan yang dilalui manusia dalam bidang kehidupannya. Dari arti kurikulum tersebut, maka dalam konteks pendidikan, kurikulum berarti jalan terang yang dilalui oleh guru dan peserta didik untuk menggabungkan pengetahuan, keterampilan, serta nilai-nilai. ${ }^{5}$ Pentingnya pola pengembangan kurikulum berkarakter untuk semua kalangan terutama di pesantren memunculkan berbagai strategi dalam menerapkanya. Strategi internalisasi dan integrasi yang dilakukan oleh berbagai lembaga untuk menjadikan peserta didik mendapatkan hasil yang maksimal. ${ }^{6}$ Atas dasar pengertian tersebut berarti dalam hal pendidikan pun harus ada acuan, pedoman dasar rambu - rambu yang pasti tentang bahan ajar (materi yang diajarkan) dari mana mulai diajarkan dan kapan berakhir, serta bagaimana cara menguasai bahan agar dapat mencapai hasil sesuai dengan yang diharapkan. ${ }^{7}$

\footnotetext{
Mohammad Ansyar, Kurikulum Hakikat Fondasi Desain dan Pengembangan, Jakarta: Kencana, 2017, 24

Sulistyo, Manajemen Pendidikan Islam: Konsep, Strategi, dan Aplikasi(Yogyakarta: Teras, 2009), 38-39 ejournal.stainpamekasan.ac.id/index.php/tadris/article/1635 Suparta,Pengantar Teori dan Aplikasi Pengembangan Kurikulum PAI. (JAKARTA: RajaGrafindo Persada,2016),ce. Ke 1, 1.
} 
Pada tahun 1855 istilah kurikulum digunakan dalam dunia pendidikan yang mengandung arti sejumlah mata pelajaran pada perguruan tinggi. Dalam pandangan klasik, kurikulum dipandang sebagai rencana di suatu sekolah atau madrasah, pelajaranpelajaran dan materi apa yang harus ditempuh di sekolah itulah kurikulum. ${ }^{8}$ Kurikulum sebagaimana yang dikemukakan oleh Sukmadinata memiliki beberapa karakteristik :

1. Kurikulum sebagai suatu substansi yaitu sebuah rencana kegiatan belajar para siswa di sekolah, yang mencakup rumusan rumusan tujuan, bahan ajar, proses kegiatan pembelajaran, jadwal dan evaluasi.

2. Kurikulum sebagai sebuah sistem yaitu kurikulum merupakan rangkaian konsep tentang berbagai pembelajaran yang masing masing unit kegiatan memiliki keterkaitan.

3. Kurikulum merupakan sebuah konsep yang dinamis yakni kurikulum merupakan konsep yang terbuka dengan berbagai gagasan perubahan. ${ }^{9}$

Kurikulum sebagai suatu sistem menyangkut penentuan segala kebijakan tentang kurikulum, susunan personalia dan prosedur pengembangan kurikulum, penerapan, evaluasi, dan

Dede Rosyada, Paradikma Pendidikan Demokratis (Jakarta: Kencana 2004), 47. 
penyempurnaannya. Fungsi utama sistem kurikulum adalah pengembangan, penerapan, evaluasi, dan penyempurnaannya, baik sebagai dokumen tertulis maupun aplikasinya dan menjaga agar kurikulum tetap dinamis. ${ }^{10}$

Di dalam kajian praktisi pendidikan dan pakar pendidikan, banyak persepsi tentang pemahaman kurikulum. Karena itu, terdapat berbagai macam pengertian atau pemahaman sekitar kurikulum. Beberapa pemahaman tersebut adalah sebagai berikut :

a. Kurikulum dipandang sebagai suatu bahan tertulis yang berisi uraian tentang program pendidikan suatu sekolah yang harus dilaksanakan dari tahun ketahun.

b. Kurikulum ditulis sebagai bahan tertulis untuk digunakan para guru dalam melaksanakan tugasnya sebagai pendidik.

c. Kurikulum adalah suatu usaha untuk menyampaikan asas-asas dan ciri-ciri yang terpenting dari suatu rencana dalam bentuk yang sedemikian rupa, sehingga dapat dilaksanakan guru di sekolah.

10 Nana Syaodih Sukmadinata, Pengembangan Kurikulum, Bandung, Rosdakarya, 2019, 7. 
d. Kurikulum diartikan sebagai tujuan pengajaran, pengalaman pengalaman belajar, alat-alat pelajaran, dan cara cara penilaian yang direncanakan dan digunakan dalam pendidikan.

e. Kurikulum dipandang sebagai program pendidikan yang direncanakan dan dilaksanakan untuk mencapai tujuan tujuan pendidikan tertentu. ${ }^{11}$ Dalam beberapa pendapat, maka pemahaman pemahaman tersebut dapat dikelompokan menjadi dua, yaitu sebagai berikut:

1. Kelompok yang memandang kurikulum sebagai suatu rencana atau bahkan tertulis yang dapat dijadikan pedoman bagi para guru di sekolah.

2. Kelompok yang memandang kurikulum sebagai program yang direncanakan dan dilaksanakan dalam situasi yang nyata di kelas.

Kurikulum memang di peruntukan untuk peserta didik, seperti yang diungkapkan Murray Print yang mengungkapkan bahwa kurikulum meliputi :

a. Planned learning experiences;

b. Offered within an education institution / program;

c. Represented as a document;

d. Includes experiences resulting from implementing that document.

Eveline Siregar dan Rana Hartini. Teori Belajar dan Pembelajaran. (BOGOR:Ghalia Indonesia, 2017 ), cet. Ke -3, 62. 
Print memandang bahwa sebuah kurikulum meliputi perencanaan pengalaman belajar, program lembaga pendidikan yang di wujudkan sebuah dokumen yang telah disusun. ${ }^{12}$ Dari penelusuran konsep yang diuraikan oleh Print, pada dasarnya kurikulum memiliki tiga dimensi, yakni kurikulum sebagai mata pelajaran, kurikulum sebagai pengalaman belajar, dan kurikulum sebagai perencanaan program pembelajaran.

Pengertian kurikulum sebagai sejumlah mata pelajaran yang harus ditempuh oleh peserta didik, merupakan konsep kurikulum yang sampai saat ini banyak mewarnai teori teori dan praktik pendidikan. ${ }^{13}$

Pengertian kurikulum sebagai mata dan isi pelajaran dapat dikemukakan dari definisi yang ditemukan oleh robert M. Hutchins yang menyatakan : The curriculum should include grammer, reading, thetoric and logic, and mathematic, and additon at the secondary level introduce the great books of the western word.

Di dalam konsep kurikulum sebagai mata pelajaran biasanya erat kaitannya dengan usaha untuk memperoleh ijazah. Ijazah sendiri pada umumnya menggambarkan kemampuan. Artinya, apabila peserta

\footnotetext{
12 Yeni Nuraeni.Bahan Ajar Pengembangan Kurikulum BOGOR:Cahaya Pelajar,2017.), cet ke $1, .3$

Ibid., . 4
} 
didik telah berhasil mendapatkan ijazah berarti dia telah mampu dan menguasai sesuai kurikulum yang berlaku. Kemampuan tersebut tercermin dalam nilai setiap mata pelajaran yang terkandung dalam ijazah itu. Siswa yang belum memiliki kemampuan atau memperoleh nilai berdasarkan standar tertentu tidak akan mendapatkan ijazah, walaupun mungkin saja mereka telah mempelajari kurikulum tersebut.14Maka dengan demikian pula dalam pandangan ini kurikulum berorientasi kepada materi atau isi pelajaran. Penguasan isi materi dalam proses pembelajaran merupakan sasaran akhir dalam proses pendidikan. Untuk mengetahui apakah peserta didik telah mampu menguasai memahami materi pelajaran atau belum biasanya dilaksanakan tes hasil belajar.

Kurikulum merupakan sebuah ruh dalam dunia pendidikan, dengan makna bahwa kurikulum merupakan salah satu komponen dari beberapa komponen lainnya, yang akan menentukan kemana arah maju atau mundurnya kualitas pendidikan dalam suatu lembaga secara khusus dan dalam sebuah negara agar lebih luas lagi. ${ }^{15}$ Beragam persepsi mengenai pengertian kurikulum yang tidak lepas dari adanya

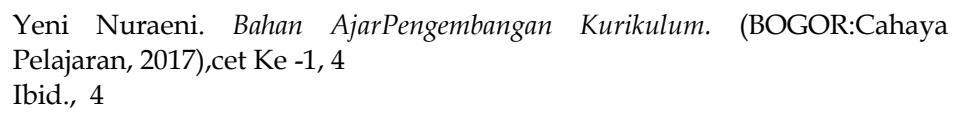

Yeni Nuraeni. Bahan AjarPengembangan Kurikulum. (BOGOR:Cahaya Pelajaran, 2017), cet Ke -1, 4 Ibid., 4 
sudut

pandang

yang

berbeda

menimbulkan

keberagaman

dalam

mengimplementasikan kurikulum itu sendiri. Secara etimologis kurikulum berasal dari kata Currere (=latin), yang bermakna berlari cepat, maju dengan cepat, menjelajahi, merambat, mengelilingi lapangan, gelanggang perlombaan dan sejenisnya. Pada mulanya kata ini lazim digunakan pada bidang atletik, namun dalam perkembangan selanjutnya diadopsi sebagai perbendaharaan umum di dunia pendidikan.

Dalam perjalanan Sejarah perkembangan kurikulum di Indonesia kami batasi sejak dikumandangkan Proklamasi Kemerdekaan Negara Kesatuan Republik Indonesia 17 Agustus 1945 hingga saat ini, dengan demikian Kurikulum yang dibuat adalah Kurikulum Nasional. Adapun Kurikulum Pendidikan Nasional telah mengalami 8 kali perubahan, yakni pada tahun 1947, 1952, 1964, 1968, 1975, 1984, 1994, 2004, 2006, 2013 dan disempurnakan dengan kurikulum Nasional. Perubahan tersebut bisa dikatakan sebagai konsekuensi logis dari terjadinya perubahan sistem politik, sosial budaya, ekonomi serta perkembangan ilmu pengetahuan dan teknologi dalam hidup dan kehidupan bermasyarakat, berbangsa dan bernegara. Oleh sebab itu, kurikulum sebagai 
seperangkat rencana pendidikan perlu dikembangkan secara dinamis sesuai dengan tuntutan dan perubahan yang terjadi di masyarakat. Semua kurikulum nasional dirancang berdasarkan landasan yang sama, yaitu Pancasila dan UUD 1945, perbedaanya pada penekanan pokok dari tujuan pendidikan serta pendekatan dalam merealisasikannya. Secara akademis, kurikulum setidaknya mencakup empat komponen utama:

1) Tujuan-tujuan pendidikan yang ingin dicapai.

2) Pengetahuan, ilmu- ilmu, data-data, aktivitasaktivitas dan pengalaman dari mana-mana.

3) Metode dan cara-cara mengajar dan bimbingan yang diikuti murid-murid untuk mendorong mereka kepada yang dikehendaki dan tujuan-tujuan yang dirancang.

4) Metode dan cara penilaian yang digunakan dalam mengukur dan menilai hasil proses pendidikan yang dirancang dalam kurikulum, perubahan kurikulum mengenai tujuan maupun alat-alat atau cara-cara untuk mencapai tujuan itu. Mengubah kurikulum sering berarti turut mengubah manusia, yaitu guru, pembina pendidikan, dan mereka-mereka yang mengasuh pendidikan. Itu sebab perubahan kurikulum dianggap sebagai perubahan sosial, suatu social change. Perubahan kurikulum juga disebut 
pembaharuan atau inovasi kurikulum. Dari definisi di atas, dapat disimpulkan bahwa perubahan kurikulum berarti adanya perbedaan dalam satu atau lebih komponen kurikulum antara periode tertentu, yang disebabkan oleh adanya usaha yang disengaja mengubah semua yang terlibat di dalamnya, yaitu guru, murid, kepala sekolah, pemilik sekolah, juga orang tua dan masyarakat umumnya yang berkepentingan dalam pendidikan. ${ }^{16}$ Dalam perubahan kurikulum dapat bersifat sebagiansebagian, tetapi dapat pula bersifat menyeluruh. Adapun perubahan kurikulum sebagai berikut:

a) Perubahan sebagian-sebagian

Perubahan yang terjadi hanya pada komponen (unsur) tentu saja dari kurikulum kita sebut perubahan yang sebagian-sebagian. Perubahan dalam metode mengajar saja, perubahan dalam itu saja, atau perubahan dalam sistem penilaian saja, adalah merupakan contoh dari perubahan sebagian-sebagian.

Dalam perubahan sebagian-sebagian ini, dapat terjadi bahwa perubahan yang berlangsung pada komponen tertentu sama sekali tidak berpengaruh terhadap komponen yang lain. 
Sebagai contoh, penambahan satu atau lebih bidang studi kedalam suatu kurikulum dapat saja terjadi tanpa membawa perubahan dalam cara (metode) mengajar atau sistem penilaian dalam kurikulum tersebut.

b) Perubahan menyeluruh

Disamping secara sebagian-sebagian, perubahan suatu kurikulum dapat saja terjadi secara menyeluruh artinya keseluruhan sistem dari kurikulum tersebut mengalami perubahan makna tergambar baik di dalam tujuannya, isinya organisasi dan strategi dan pelaksanaannya. Perubahan dari kurikulum 1968 menjadi kurikulum 1975 dan 1976 lebih merupakan perubahan kurikulum secara menyeluruh. Demikian pula kegiatan pengembangan kurikulum sekolah pembangunan mencerminkan pula usaha perubahan kurikulum yang bersifat menyeluruh. Kurikulum 1975 dan 1976 misalnya, pengembangan, tujuan, isi, organisasi dan strategi pelaksanaan yang baru dan dalam banyak hal berbeda dari kurikulum sebelumnya, ada sejumlah faktor yang dipandang mendorong terjadinya perubahan kurikulum pada berbagai Negara dewasa ini, yaitu: 
1. Bebasnya sejumlah wilayah tertentu di dunia ini dari kekuasaan kaum kolonialis. Dengan merdekanya Negara-negara tersebut, mereka menyadari bahwa selama ini mereka telah dibina dalam suatu sistem pendidikan yang sudah tidak sesuai lagi dengan cita-cita nasional merdeka. Untuk itu, mereka mulai merencanakan adanya perubahan yang cukup penting di dalam kurikulum dan sistem pendidikan yang ada.

2. Perkembangan IPTEK yang pesat sekali. Di satu pihak, perkembangan dalam berbagai cabang ilmu pengetahuan yang diajarkan di sekolah menghasilkan ditemukannya teori-teori yang lama. Di lain pihak, perkembangan di dalam ilmu pengetahuan psikologi, komunikasi, dan lain-lainnya menimbulkan ditemukannya teori dan cara-cara baru di dalam proses belajar mengajar. Kedua perkembangan di atas, dengan sendirinya mendorong timbulnya perubahan dalam isi maupun strategi pelaksanaan kurikulum. Pertumbuhan yang pesat dari penduduk dunia dengan bertambahnya penduduk, maka makin bertambah pula jumlah orang yang 
membutuhkan pendidikan. Hal ini menyebabkan bahwa cara atau pendekatan yang telah digunakan selama ini dalam pendidikan perlu ditinjau kembali dan kalau perlu diubah agar dapat memenuhi kebutuhan akan pendidikan yang semakin besar. Ketiga faktor di atas itulah yang secara umum banyak mempengaruhi timbulnya perubahan kurikulum yang kita alami dewasa ini. Perkembangan kurikulum seperti spiral, tidak sebagai lingkaran, jadi kita tidak kembali kepada yang lama, tetapi pada suatu titik di atas yang lama. Kurikulum yang digunakan di Indonesia dipengaruhi oleh tatanan sosial politik Indonesia. Negara-negara penjajah yang mendiami wilayah Indonesia ikut juga mempengaruhi sistem pendidikan di Indonesia. Sistem pendidikan Belanda diatur dengan prosedur yang ketat dari mulai aturan siswa, pengajar, sistem pengajaran, dan kurikulum. Sistem prosedural seperti ini sangat berbeda dengan sistem prosedural pada sistem pendidikan Islam yang telah dikenal sebelumnya. Sistem pendidikan belanda pun bersifat diskriminatif. Sekolah-sekolah 